\title{
A method to measure captive giant otters (PTERonura brasiliensis) WITHOUT SEDATION
}

\author{
Fernando C. W. Rosas ${ }^{1,2}$, Carla S. da Rocha ${ }^{1}$ and Gália Ely de Mattos ${ }^{1}$
}

The giant otter, Pteronura brasiliensis, is one of the largest carnivores of South America (Duplaix, 1980). Its historical distribution extended from the northern part of the South American continent to the north-central portion of Argentina (Carter and Rosas, 1997). Because of the destruction of its habitat and intense hunting pressure due to the demand of the international "haute couture" for giant otter skins, P. brasiliensis numbers had decreased significantly by the early 1970s. The species is classified as endangered by The World Conservation Union (IUCN, 2006). Currently, it is believed that $P$. brasiliensis is extinct in the southern portion of its historical distribution; however stable populations can still be found in the Pantanal and Amazon (Rosas et al., 1991; Carter and Rosas, 1997; Rosas, 2004). Although the species is threatened, much information regarding its basic biology and morphometrics still remains scarce. According to Duplaix (1980) the morphometric data, such as maximum length and weight, mentioned in the literature for $P$. brasiliensis are tentative at best.

The genus Pteronura is monospecific. Although it has not been scientifically proven, two subspecies are mentioned in the literature: P. brasiliensis brasiliensis distributed in the Amazon Basin; and P. brasiliensis paranensis which occurs in the Paraguay and Paraná river basins, including the Pantanal wetland area (Harris, 1968; Duplaix, 1980). Genetic studies are necessary to confirm the existence of species division. According to Harris (1968) the total length of P. b. paranensis is shorter than that of $P$. brasiliensis brasiliensis. One difficulty in assessing captive giant otters involves the ability to adequately follow-up the animals' morphometrics. Giant otters are very active carnivores with high metabolic rates (Carter et al., 1999), requiring special handling procedures in captivity. As a rule of thumb, the body measurements of cubs and juveniles can be obtained by the physical restraint of the animal. However, adult animal morphometrics can only be obtained using sedatives. It is important to stress that in addition to the costs, chemical contention involves a preliminary physical restrain in order to apply the anesthetics, and requires further care procedures because side effect reactions can occur (Marsicano et al., 1986). Additionally, anesthetic procedures, in general, are not justifiable for only obtaining morphometric data. Although giant otters can be weighed at a low cost using special cages in which the animals are contained and weighed, obtaining the total length of captive giant otters has always been a challenge for institutions. The aim of this study was to obtain reliable total length estimates of captive giant otters without the use of anesthetics. Knowing that giant otters rest during the day on top of trunks or other objects in the enclosure, we tested the use of previously calibrated plywood boards strategically placed inside the enclosures at the National Institute of Amazonian Research (INPA). The boards, which were $400 \mathrm{~cm}$ long, $26.5 \mathrm{~cm}$ wide, and $4.5 \mathrm{~cm}$ thick, were painted yellow and marked every $5 \mathrm{~cm}$ with alternating black and red paint (Figure 1).

The calibrated plywood boards were placed in such a way that allowed the animals to lay on them. The animals were observed systematically by two independent observers at different times of the day, especially around 12:00pm and the end of the afternoon before entering their dens for the night. Good weather was taken into consideration as well. Each time the otters laid on the board in a specific position, where the entire body of the animal is stretched, from the snout to the tip of the tail, on top of the plywood board (Figure 1), the total length was estimated using the $5 \mathrm{~cm}$ marks that were painted on the board. An adaptation period was necessary in order for the giant otters to become accustomed to the boards and the presence of the observer.

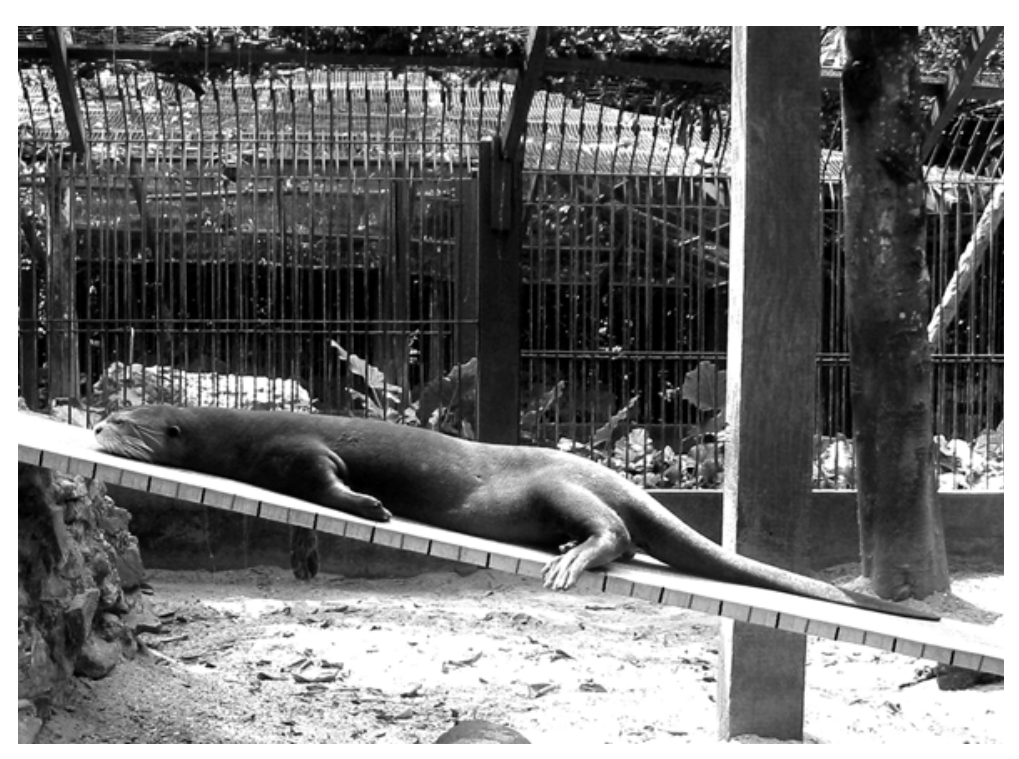

Figure 1. Giant otter lying down with its entire body stretched, from the snout to the tip of the tail, on a plywood board at the National Institute of Amazonian Research (INPA), Manaus, AM, Brazil.

\footnotetext{
${ }^{1}$ Instituto Nacional de Pesquisas da Amazônia (INPA), Laboratório de Mamíferos Aquáticos. Caixa Postal 478, 69011-970, Manaus AM Brazil.

${ }^{2}$ E-mail: frosas@inpa.gov.br.
} 
This period ranged from three to four days depending on the animals' behavior and the enclosure layout (visitation area, noise exposure, etc.). It is important to note that observations must take place on days when no visits are allowed and that disturbances are kept to a minimum around the enclosure.

In order to ensure greater precision in these estimates, a digital camera was used. The estimated measurements obtained in captivity by the observer were compared with the digital images in order to double-check the obtained total length estimations.

After body length estimations were obtained using the plywood boards, all giant otters used in this experiment were anesthetized for further hematological and genetic studies. Their total body lengths were measured in a straight line from the tip of the snout to the tip of the tail according to IBAMA (2001).

In all cases, the total length measurements obtained using the plywood board method were less than the actual body length of the giant otters obtained via direct handling. However, the maximum error observed was only 3.3\% and this is probably due to the slight elevation of the pelvic region of the animals when laying down on the plywood board, which does not happen with anesthetized individuals. The observer always stays at a $90^{\circ}$ angle from the animals on the plywood board in order to be perpendicular to the marks, thereby avoiding possible distortions while estimating the total length of a giant otter. Comparisons of the observed total lengths of the animals measured in a straight line with the estimated total lengths obtained using the plywood boards are listed in Table 1. The results indicate that this method allows for reliable total length estimates, although it does require the animals to remain properly positioned on the plywood board.

When properly applied, this low cost, simple method can help institutions obtain a good estimation of the total length of their $P$. brasiliensis individuals. The maximum body length reported for the species still remains controversial in the literature. This method, however, may help institutions clarify the morphometrics of this species.

\section{Acknowledgments}

We would like to thank the veterinarian José Anselmo d'Affonseca Neto and the PREVET staff for their help during the animal-restraining process. We also would like to thank Tasianne Barros B. de Araújo for her help during the data collection process. We also extend our gratitude to Kesä K. Lehti who assisted with the revised English version of this manuscript.

We would like to express our gratitude to two anonymous reviewers for constructive comments on the manuscript.

Table 1. Comparison of observed total body length (measured with giant otters anesthetized) and estimated total body length using the plywood boards.

\begin{tabular}{|c|c|c|c|c|}
\hline ANIMAL NAME & GENDER & $\begin{array}{c}\text { OBSERVED } \\
\text { TOTAL LENGTH }(\mathrm{cm}) \\
\end{array}$ & $\begin{array}{c}\text { ESTIMATED } \\
\text { TOTAL LENGTH }(\mathrm{cm})\end{array}$ & $\begin{array}{c}\text { MARGIN } \\
\text { OF ERROR (\%) }\end{array}$ \\
\hline Twaka & $\sigma^{\prime}$ & 150.0 & 145.0 & 3.30 \\
\hline Kiwa & $\sigma^{\circ}$ & 156.5 & 155.0 & 0.96 \\
\hline Neewi & 우 & 159.0 & 158.0 & 0.63 \\
\hline Wani & 우 & 160.0 & 156.0 & 2.50 \\
\hline
\end{tabular}

\section{References}

CARTER, S.K. AND ROSAS, F.C.W. (1997) Biology and conservation of the giant otter Pteronura brasiliensis. Mammal Review 27:1-26.

CARTER, S.K., ROSAS, F.C.W., COOPER, A.B. AND CORDEIRO-DUARTE, A.C.O. (1999) Consumption rate, food preferences and transit time of captive giant otter, Pteronura brasiliensis: Implications for the study of wild populations. Aquatic Mammals 25:79-90.

Duplaix, N. (1980) Observations on the ecology and behavior of the giant river otter Pteronura brasiliensis in Suriname. Revue Ecologique (Terre Vie) 34:495-620.

HARris, C.J. (1968) Otters: a study of the recent Lutrinae. Weidenfeld and Nicolson, London.

IBAMA (2001) Mamíferos aquáticos do Brasil: plano de ação. Versão II, segunda edição. Instituto Brasileiro do Meio Ambiente e dos Recursos Naturais Renováveis. Brasília - DF, 102 pp.

IUCN (2006). 2004 IUCN Red List of Threatened Species. $<$ www.iucnredlist.org>. Downloaded on 13 January 2006.

Marsicano, G., Rosas, M.M., Rosas, F.C.W and Souza, R.H.S. (1986) Contenção de lontras amazônicas com Cloridrato de ketamina. A Hora Veterinária 6:5-8.

Rosas, F.C.W. (2004) Ariranha Pteronura brasiliensis. Pages 265269 in Cintra, R. (Ed.) Historia Natural, Ecologia e Conservação de Algumas Espécies de Plantas e Animais da Amazônia. EDUA/ INPA, Manaus, Amazonas, Brasil.

Rosas, F.C.W., Colares, E.P., Colares, I.G. and Silva, V.M.F. DA (1991) Mamíferos aquáticos da Amazônia. Pages 405-411 in VAL, A.L., Figliuolo, R. and Feldberg, E. (Eds) Bases Científicas para Estratégias de Preservação e Desenvolvimento da Amazônia: Fatos e perspectivas. Vol. I Manaus, AM, Brazil. 